\title{
QUEEN'S
UNIVERSITY
BELFAST
}

\section{The influence of parents, older siblings, and non-parental care on infant development at nine months of age}

Cruise, S., \& O'Reilly, D. (2014). The influence of parents, older siblings, and non-parental care on infant development at nine months of age. Infant behavior \& development, 37(4), 546-555.

https://doi.org/10.1016/j.infbeh.2014.06.005

\section{Published in:}

Infant behavior \& development

\section{Document Version:}

Peer reviewed version

Queen's University Belfast - Research Portal:

Link to publication record in Queen's University Belfast Research Portal

\section{Publisher rights \\ Copyright 2014 Elsevier}

This is the author's version of a work that was accepted for publication in Infant Behavior and Development. Changes resulting from the publishing process, such as peer review, editing, corrections, structural formatting, and other quality control mechanisms may not be reflected in this document. Changes may have been made to this work since it was submitted for publication. A definitive version was subsequently published in Infant Behavior and Development, [VOL 37, ISSUE 4, (November 2014)] doi:10.1016/j.infbeh.2014.06.005

\section{General rights}

Copyright for the publications made accessible via the Queen's University Belfast Research Portal is retained by the author(s) and / or other copyright owners and it is a condition of accessing these publications that users recognise and abide by the legal requirements associated with these rights.

Take down policy

The Research Portal is Queen's institutional repository that provides access to Queen's research output. Every effort has been made to ensure that content in the Research Portal does not infringe any person's rights, or applicable UK laws. If you discover content in the Research Portal that you believe breaches copyright or violates any law, please contact openaccess@qub.ac.uk. 
The influence of parents, older siblings, and non-parental care on infant development at nine months of age

Sharon Cruise ${ }^{1}$

Dermot O’Reilly ${ }^{1,2}$

${ }^{1}$ Centre for Public Health, Queen's University Belfast, Belfast, Northern Ireland, United Kingdom

${ }^{2}$ UKCRC Centre of Excellence for Public Health (NI), Centre for Public Health, Queen's University Belfast, Belfast, Northern Ireland, United Kingdom

\begin{abstract}
Background The majority of research examining the influence of social environment on early child development suggests benefits to two-parent households, but contradictory evidence for the effects of siblings. The aims of the present study were to examine the influence of the child's proximal social environment, and the effects of interactions between socioeconomic status and social environment on developmental outcomes.
\end{abstract}

Methods Primary caregivers of a representative sample of 10,748 nine-month-old infants in Ireland completed the Ages and Stages Questionnaire and provided information on social environment. Adjustment was made for infant and maternal characteristics, household income, and area where the child was living at the time of the study. Further analyses tested for interactions between social environment and household income.

Results Binary logistic regressions indicated no effects for number of parents in the household. However, the presence of siblings in the household was a consistent predictor of 
failing to reach milestones in communication, gross motor, problem-solving, and personalsocial development. Furthermore, there was a gradient of increasing likelihood of failing in gross motor, problem-solving, and personal-social development with increasing numbers of siblings. Care by a grandparent decreased the likelihood of failing in communication and personal-social development.

Conclusions These findings do not support the majority of research that finds positive benefits for two-parent households. Similarly, the findings suggest limited effects for nonparental care. However, the observed negative effects of siblings support both the confluence and resource dilution models of sibling effect. Examination of follow-up data may elucidate current findings.

Keywords: infant development; parents; siblings; non-parental care 


\title{
The influence of parents, older siblings, and non-parental care on infant development at nine months of age
}

\begin{abstract}
Background The majority of research examining the influence of social environment on early child development suggests benefits to two-parent households, but contradictory evidence for the effects of siblings. The aims of the present study were to examine the influence of the child's proximal social environment, and the effects of interactions between socioeconomic status and social environment on developmental outcomes.
\end{abstract}

Methods Primary caregivers of a representative sample of 10,748 nine-month-old infants in Ireland completed the Ages and Stages Questionnaire and provided information on social environment. Adjustment was made for infant and maternal characteristics, household income, and area where the child was living at the time of the study. Further analyses tested for interactions between social environment and household income.

Results Binary logistic regressions indicated no effects for number of parents in the household. However, the presence of siblings in the household was a consistent predictor of failing to reach milestones in communication, gross motor, problem-solving, and personalsocial development. Furthermore, there was a gradient of increasing likelihood of failing in gross motor, problem-solving, and personal-social development with increasing numbers of siblings. Care by a grandparent decreased the likelihood of failing in communication and personal-social development.

Conclusions These findings do not support the majority of research that finds positive benefits for two-parent households. Similarly, the findings suggest limited effects for nonparental care. However, the observed negative effects of siblings support both the confluence 
and resource dilution models of sibling effect. Examination of follow-up data may elucidate current findings.

Keywords: infant development; parents; siblings; non-parental care 


\section{Introduction}

There are growing concerns about the increasing prevalence of childhood socioemotional/behavioural problems (Brauner \& Stephens, 2006; Cooper, Masi, \& Vick, 2009) and the impact of these on longer term outcomes (Fergusson, Horwood, \& Ridder, 2005; Jokela, Ferrie, \& Kivimaki, 2009). Moreover, developmental delay is a cause for concern, with even subtle delays being sufficient to impact on school readiness, educational outcomes, and employment prospects (American Academy of Pediatrics, 2001; Shonkoff \& Phillips, 2000).

As disruptions to developmental trajectories may stem from the child's proximal social environment, there is an imperative to understand how the social environment of the child impacts on developmental outcomes. The majority of research suggests that children's behaviour and development benefit by living within a stable, two-parent household, either because of the greater availability of assets/resources (McLanahan \& Sandefur, 1994), or because a single parent is less able to provide adequate and appropriate monitoring and structure (Carlson \& Corcoran, 2001; Hofferth \& Anderson, 2003; Magnuson \& Berger, 2009; Wu \& Martinson, 1993). However, older studies (Belsky, 1979, 1981; Lytton, 1979) suggest that there can be 'second-order effects' on children whereby the presence of two parents may result in reduced interaction with the infant as the parents are focused on interacting with each other.

Siblings are another important proximal influence on a young infant. The confluence model by Zajonc and Markus (1975) (see also Zajonc, 2001) argues that parental resources are stretched with each additional child, meaning younger children may spend increased amounts of time with older siblings who cannot provide the quality of cognitive stimulation that would 
be provided by parents. Similarly, resource dilution theory proposes that all resources within the family, be they financial or in terms of parental time and energy, are 'diluted' as the family size increases (Blake, 1981). There have been suggestions that the effects of resource dilution are modified by socioeconomic status, with children from lower income families being more adversely affected than those from higher income families (Marjoribanks, 1997; Rodgers, 2001). Moreover, it is reasonable to hypothesise that children being raised by a single parent may be especially susceptible to the effects of increasing family size.

Studies that have found negative effects for the influence of siblings would appear to support resource dilution theory and the confluence model. For example, a recent study by Koutra et al. (2012) found that the presence of older siblings had a negative effect on specific areas of development (cognitive, gross motor, and communication) in 18-month-old infants. However, not all studies show negative effects for siblings. In a study among 551 children aged five years, Freijo et al. (2008) did not find any effects for the presence of siblings on cognitive development, while Brody (2004) has suggested that younger siblings may benefit by learning from older siblings. Similarly, Hetherington (1988) suggested that the presence of siblings allows the developing child to learn how to resolve conflict, and that siblings represent an additional source of nurturance. Conversely, Bank, Patterson, and Reid (1996) argue that problem behaviour in older children can transfer to their younger siblings. Given the lack of consistency in the findings of previous studies in relation to the effects of siblings, further research is clearly warranted, and should also consider the effects of both singleparent households and low household income. Moreover, it should be noted there was wide variability in the age groups of children in previous studies that have examined the effects of siblings, but fewer that included children of younger ages. Further research is therefore warranted examining the effects of siblings at the early stages of development. 
Whilst most young children will be exposed to multiple influences from key figures other than parents and siblings (i.e., usually relatives, friends, and neighbours), some will receive more concentrated forms of non-parental care, usually whilst the primary caregiver is at work (Belsky et al., 2007). Such care may be provided by a grandparent or other relative, a nonrelative, a formal centre-based childcare provider, or any combination of these. It is beyond the scope of the present study to provide an in-depth examination of the effects on development of different types and intensities of childcare (however, see Belsky et al., 2007; Gray, 2005; Hank \& Buber, 2009; Koslowski, 2009 for recent overviews relating to childcare); the present study is primarily interested in the social environment of the developing infant, and for some infants this will include an element of non-parental care. Therefore, we have considered whether or not the child receives non-parental care, and whether that care comes primarily from a relative, non-relative, or formal centre-based childcare provider.

The primary aim, therefore, of the present study was to examine the influence of parents, siblings, and aspects of non-parental care on infant development. However, it is acknowledged that these factors are potentially confounded by a number of other factors that are known to influence infant development. A brief overview is provided below.

\subsection{Infant characteristics}

Both infant gestational age and infant birthweight may be associated with longer-term negative outcomes (e.g., McCormick, Litt, Smith, \& Zupancic, 2011; Richards, Hardy, Kuh, \&Wadsworth, 2001). Moreover, there may be an interaction between birthweight and birth order insofar as firstborns tend to have lower birthweights than later borns (e.g., Khong, 
Adema, \& Erwich, 2003; Wilcox, Chang, \& Johnson, 1996). Therefore, this variable must be controlled for when examining the effects of siblings, as birth position may influence birthweight.

It is acknowledged that birthweights for male children are traditionally higher than for female children (Kramer, 1987; Kramer et al., 2001) which may convey an advantage. However, research also indicates that boys are at increased risk of preterm birth and perinatal complications (Brettell, Yeh, \& Impey, 2008; Di Renzo, Rosati, Sarti, Cruciani, \& Cutuli, 2007; Sheiner et al., 2004). As such, it is important to adjust for gender in any analyses that seeks to examine the effects of social environment on developmental outcomes as there may be interactions between gender, gestational age, and birthweight.

\subsection{Socioeconomic status and maternal characteristics}

The most obvious possible confounding variable to take in to consideration is that of socioeconomic status (SES) and family/household income. There is ample evidence for the negative effects of low SES on child health and developmental outcomes (cognitive and social/emotional/behavioural) (e.g., Bradley \& Corwyn, 2002; Duncan \& Brooks-Gunn, 1997; McLoyd, 1998; Votruba-Drzal, 2003, 2006).

Associated with SES are maternal age, education, and ethnicity. Women from low SES backgrounds are more likely to become mothers at an earlier age, to have larger families, and to have reached a lower level of educational attainment (see Spencer, 2000). These factors have an additive/cumulative effect, and often have their roots in the mother's own early life history. Therefore, it is imperative to adjust for such variables in any analysis that seeks to understand the effects of the social environment on infant health and development. 


\subsection{Region}

With respect to the possible effects of living in an urban versus a rural area, there may be potential interactions between region and childcare insofar as families living in rural areas may not have the same access to non-parental care, especially formal centre-based childcare, as those living in urban areas.

In summary, it is important to gain an understanding of the effects of the child's social environment on all domains of development, and at as early an age as possible. Whilst a number of studies have examined the effects of parental type (i.e., single versus dual parent families) and presence/number of siblings on child development, findings continue to be contradictory. Furthermore, few studies have focused on children aged less than one year, and not all studies have considered a range of abilities that encompass both cognitive and behavioural aspects of development. Finally, many of the previous studies have been conducted among small, non-representative samples that limit the extent to which known confounders can be controlled.

Therefore, the aims of the present study were to examine the influence of the child's proximal social environment on five areas of development in a large, representative sample of ninemonth-old infants in the Republic of Ireland. Specifically, it was predicted that infants who are being raised in families with less material and human resources (such as lone parents with larger families, low incomes, and/or limited support with childcare) will be less likely to reach their developmental milestones. 


\section{Methods}

\subsection{Sample population}

Respondents were the primary caregivers of 10,748 singleton nine-month-old infants who were recruited to Wave 1 (baseline) of the Growing Up in Ireland (GUI) study, a nationally representative prospective cohort study commissioned by the Irish Government to examine factors associated with the health and well-being of children living in the Republic of Ireland (see http://www.growingup.ie/index.php?id=9 for detailed information about the GUI study). Infants and their families were randomly selected from a total population of 73,662 infants who were recorded on the Child Benefit Register in 2008. The sample response rate was $65 \%$ of all families who were approached to take part in the study. Data for the baseline infant cohort was collected between September 2008 and April 2009 (see Thornton, Williams, McCrory, Murray, \& Quail, 2013, for more detailed information on the study design and methodology for the GUI study). Ethical approval was granted by an independent Research Ethics Committee that was organised by the Department of Health and Children (Dublin, Republic of Ireland) specifically and solely for the infant cohort of the Growing Up in Ireland study.

\subsection{Measurements}

\subsubsection{Outcome variable}

Primary caregivers completed the Ages and Stages Questionnaire ( $2^{\text {nd }}$ edition; ASQ), a parent-report measure that can be used to screen for developmental problems from the age of four to 60 months in the following five domains of ability: communication, gross motor, fine motor, problem-solving, and personal-social (Squires, Bricker, \& Potter, 1997; Squires, Potter, \& Bricker, 1999). The ASQ is a validated instrument that has been standardised in large samples of infants and children. The developers of the scale report a $94 \%$ agreement 
between parental report using the ASQ and clinician assessment of developmental status (Squires et al., 1999). Scores for each subscale can range from 0 to 60, with higher scores reflecting higher skill levels. The current study has used a 'fail' cut-off criterion of $\geq 2$ standard deviations below the mean for each individual subscale which is recommended by the developers of the scale (Squires et al., 1997, 1999).

\subsubsection{Explanatory variables}

Primary caregivers provided socio-environmental information, including whether there was a partner resident in the household (has partner [ref], no partner), the number of siblings resident in the household (none [ref], 1 sibling, 2 or more siblings), and whether the infant was receiving non-parental care from a relative, non-relative, or a centre-based facility (each coded as yes, no [ref]).

\subsubsection{Confounding variables}

Primary caregivers also provided information about the infant's gestational age (25-36 weeks, 37-41 weeks [ref], 42-46 weeks), birthweight ( $\leq 2499$ grams, 2500-3000 grams, 3001-3500 grams [ref], 3501-4000 grams, $\geq 4001$ grams), and gender (female [ref], male) ${ }^{1}$; maternal ethnicity (Irish white [ref], other white, other); maternal age (16-19, 20-24, $25-29$ [ref], 3034, 35-40+); maternal educational level (higher education [ref], secondary); equivalised household income (quintiles ranging from highest [ref] to lowest, and a sixth category comprising missing data); and whether the family lived in a rural [ref] or urban setting.

\footnotetext{
${ }^{1}$ In the preliminary stages of analysis the models were also adjusted for breastfeeding (i.e., whether the infant was ever breastfed; whether the infant was exclusively breastfed). However, this variable did not help to explain the influence of parents, siblings, or non-parental care on infant development, and in the interests of parsimony the variable was excluded from the final regression models.
} 


\subsection{Statistical analysis}

This study reports on secondary data analyses that were conducted on the GUI infant cohort study data using IBM® SPSS $®$ Statistics 21 .

Weighted frequency analyses were conducted for all explanatory variables included in the regression analyses (see column one of Table 1), for the number of infants who failed any one domain of development (see column two of Table 1), and for the number of infants in the 'fail' categories for each domain of development (see remaining columns of Table 1).

In order to address the primary aim of the research, a series of binary logistic regressions were conducted, with variables being entered in five blocks (1. social environment; 2 . infant factors; 3. maternal factors; 4. household characteristics; 5. area of residence), with the fifth and final block representing the fully adjusted multivariate model. The rationale for entering the blocks of variables in this order were that of moving from the variables that are most proximal to the infant (i.e., social environment) to those that are the most distal (i.e., income and area where the family lives) (see Table 2). Model building was initially carried out with failing in any one of the five domains as the dependent variable (though with a sensitivity analysis using failing any two of the five domains as dependent variable). A series of fully adjusted models were then conducted with each of the five domains of development as dependent variable (see Table 3). In order to address the secondary aim of the research, each of the regression models described above were re-run with the inclusion of a series of interactions terms in order to examine the influence of presence of partner on presence of siblings, and also the effect of household income on presence of siblings. 


\section{Results}

Table 1 shows the characteristics of the study population, and the proportion who failed in any one of the domains, and in each of the five developmental domains. Approximately one in seven of the children were in one-parent families, and although mothers in single-parent families tended to be younger (e.g., $9 \%$ aged $16-19$ compared to $<1 \%$ for those in two-parent families), a significant proportion were older, with $56 \%$ aged 25 or more and $30 \%$ aged 30 or more. Single-parent families were also poorer, with $49 \%$ in the lowest income quintile compared to $13 \%$ of two-parent families. The children in single-parent families were about twice as likely as those in two-parent families to have been of low birthweight $(<2500$ grams). Overall, $43 \%$ of the children had no siblings, while $24 \%$ had two or more. The parents of single-child families tended to be younger (21.5\% aged less than 25 compared to $5.3 \%$ for those with more children) and were more affluent, with $23.0 \%$ in the most affluent quintile compared to $12.9 \%$ for the rest. Care of the child by a relative was more likely in single-parent households (26\%) compared to two-parent households (18.8\%), while centrebased care was almost twice as likely in two-parent households (11.7\%) compared to singleparent households $(6.8 \%)$. Children of older mothers had lower rates of care by a relative and higher rates of care by non-relatives and centre-based care than younger mothers. This pattern was also evident for the children of mothers in higher income groups compared to lower income groups.

$<$ TABLE 1 about here $>$

Overall, $40.2 \%$ of children failed any one of the five domains, and $14.2 \%$ failed any two. The greatest percentage of fails among the individual domains was in personal-social 
(17.4\%), and the lowest was in communication (6.5\%). Table 2 shows the likelihood of failing in any one of the domains according to the infant, maternal, household, and area characteristics. There were the anticipated gradients for infant's gestational age and birthweight, with those born before 37 weeks or with a birthweight less than 2500 grams having poorer outcomes (OR for fail 2.03 (95\% CIs 1.71,2.42) and 2.09 (95\% CIs 1.71,2.57) respectively), though because of their overlapping occurrence these odds ratios were attenuated to 1.63 and 1.62 respectively. Findings for mother's age were somewhat counterintuitive, with an increasing gradient of poorer outcomes for mothers aged over 30 . Other than a small increased risk of failure according to educational attainment, there was no overall relationship between failure and socioeconomic status as measured by equivalised household income. The patterns for models where failing in any two domains was the outcome were similar to those described above for failing in any one domain, but a little more pronounced. For example, the fully adjusted odds ratios for a child with low gestational age or low birthweight failing in any two domains were 1.94 and 1.89 compared to the 1.63 and 1.62 mentioned above.

Children in single-parent families did not appear to be disadvantaged in terms of development compared to their peers in two-parent families in either the unadjusted or fully adjusted models; their comparative likelihood of failing in any one or any two domains in the fully adjusted models were respectively 1.06 (95\% CIs $0.92,1.22)$ and $0.96(95 \%$ CIs $0.79,1.17)$. The presence of siblings increased the likelihood of failing in any one domain by approximately $40 \%$, and this was not significantly changed by adjustment for all the other factors in the model. Further analysis to explore the effects of a second sibling produced mixed results. In models where failure in any one domain was the outcome, the addition of a variable that included additional categories for one sibling, and two or more siblings did not 
significantly improve the fit $(\chi 2=1.582(1), p=0.208)$. However, a gradient was apparent where any two fails was the outcome, and the likelihood of failure increased from 1.65 (95\% CIs $1.43,1.91)$ for only one sibling to 1.93 (95\% CIs $1.64,2.28)$ for two or more siblings. Care provided by a non-relative, or by a formal child-care provider was not associated with the likelihood of failure in any one domain for either the unadjusted or fully adjusted models. Care by a relative (which in approximately $75 \%$ of cases was a grandparent) was associated with a $12 \%$ decreased likelihood of failing in any one domain in the unadjusted model (OR 0.88 ; $95 \%$ CIs $0.80,0.98$ ); however, this effect was attenuated to $5 \%$ in the fully adjusted model (OR 0.95; 95\% CIs 0.85,1.05).

$<$ TABLE 2 about here $>$

Table 3 shows the fully adjusted models for each of the five domains of the ASQ. Whilst the general pattern described for failing in any one domain persists, there are some variations when this is examined for each individual domain. Boys fared worse than girls in all domains except gross motor, and the gender gap was largest in communication (OR 1.56; 95\% CIs $1.33,1.83)$. The effects of low birthweight were also evident across the domains, though most apparent in the communication domain. The children of non-Irish white mothers were more likely to fail in the communication domain but less likely than the Irish children to fail in the gross motor and problem-solving domains. Although the model examining failing in one domain demonstrated that children of older mothers were more likely to fail, the analysis for the individual domains showed that this was only clearly evident in the problem-solving domain, and the reverse pattern was evident in the fine motor domain, with teenage mothers more likely than those in the 25-29 age band to fail (OR 1.74; $95 \%$ CIs $1.12,2.69)$. In none of the domains did the odds of a child in a single-parent 
household failing a test differ significantly from that of their peers in two-parent households. The presence of one or more siblings in the household increased the risk of failure in all domains except fine motor (OR (for two versus no siblings) 1.01; 95\% CIs 0.83,1.23). The additional input of care by relatives (in approximately $75 \%$ of cases this was by grandparents) was associated with a decreased likelihood of failure in the communication domain (OR 0.70, $95 \%$ CIs $0.55,0.87$ ) and in the personal-social domain (OR 0.84; 95\% CIs $0.73,0.97$ ), but there was no significant effect from the provision of other child caring arrangements.

$<$ TABLE 3 about here $>$

In the Introduction it was postulated that pressure on parental resources may explain some of the failures in the ASQ, and this might, for example, explain the effects of the presence of a sibling. To test this theory, a further series of analyses were undertaken to see if the effects of siblings were more pronounced for those with least resources, namely single-parent families and those families in the lowest income quintile. This was undertaken by introducing partner-by-sibling and sibling-by-income interactions into the models, as well as looking at the coefficients in stratified models. In neither case were the interactions significant (partner-by-sibling: $p=0.144, p=0.862, p=0.435, p=0.755, p=0.492, p=0.230$ for any one fail, communication, gross motor, fine motor, problem-solving, and personal-social respectively; sibling-by-income: $\mathrm{p}=0.395, \mathrm{p}=0.452, \mathrm{p}=0.496, \mathrm{p}=0.035, \mathrm{p}=0.123, \mathrm{p}=0.504$ for any one fail, communication, gross motor, fine motor, problem-solving, and personal-social respectively), indicating that the effect of siblings did not vary according to the number of parents present or to the wealth of the family. Although there was one significant interaction in the fine motor domain, this was for the effects of having one sibling by belonging to the 'missing' household income category. This income category was included in order to 
minimise any bias that could have occurred due to non-random missing data on the household income variable, but little is known about the missing cases, thus few conclusions can be drawn from the significance of this interaction.

\section{Discussion}

The aim of the present study was to examine the influence of the proximal social environment on the developmental outcomes of nine-month-old infants in the Republic of Ireland. Findings indicated that there was little evidence that infants of single mothers are disadvantaged in terms of their development compared with infants in two-parent households; that the presence of older siblings appears to be detrimental to development at nine months; and that the presence of alternative child minding arrangements is positively associated with some aspects of development at nine months when care is provided by a grandparent.

The lack of effects on development for children being raised in single and two-parent families is not in keeping with many previous studies (Carlson \& Corcoran, 2001; Hofferth \& Anderson, 2003; Magnuson \& Berger, 2009; Wu \& Martinson, 1993). However, we need to apply some caveats when interpreting these results. Firstly, these are effects observed at an earlier stage of infant development than those shown in previous studies. Moreover, these observations are cross-sectional: it is possible that any influence of a partner's presence in the household, whether positive or negative, only becomes apparent over longer time periods. Finally, the present study focused on the structural aspects of the infant's environment, but it is acknowledged that the quality/security of relationships within the family may play a role in infant development. These process elements will be a focus for future research. 
The presence of siblings was the strongest and most consistent predictor of failing to meet milestones in all areas of development except fine motor. In all cases where the presence of siblings was a significant predictor, even just one sibling was influential. For communication, the effects for one sibling, or two or more siblings were comparable; however, for the gross motor, problem-solving, and personal-social domains of development there was evidence of a gradient, with negative effects increasing as numbers of siblings increased. These findings lend support to both the confluence model and the resource dilution theory (Blake 1981; Zajonc \& Markus, 1975), and are congruent with the findings of Koutra et al. (2012) among a sample of 18-month-old infants, though contrary to the findings of Freijo et al. (2008) and to Brody's (2004) suggestion that infants may benefit by learning from siblings. It should be noted that the infants in the present sample were all last-born infants, so any observed sibling influences were attributable to older siblings, and the increasing trend may suggest that in the case of two or more siblings the study infant has an increasingly distal association with the parent(s) and a more proximal association with older siblings. The present study did not consider the age of siblings - for example, it is possible that siblings who are closer in age to the cohort child may require more parental attention, thus representing a greater drain on parental resources than would siblings who are older. Siblings whose ages are spaced further apart may represent less of a drain on parental resources, but may have more involvement in the care of the infant, thereby making the infant's relationship with the parents more distal. This is an area that warrants further study.

With respect to non-parental care, there was evidence that grandparents can have a positive influence on both communication and personal-social development in infants at nine months of age. However, there was little evidence in the present study of either positive or negative effects of other aspects of non-parental care on development. A caveat here is that it is not 
known whether these alternative child-care arrangements were complementary to, or a substitute for, parental caring. Furthermore, the study did not consider the intensity or quality of care, the age at which the infant began care, or the number of other children being cared for in that environment, factors that will be addressed in further ongoing research.

In the present study there was little evidence of the effects of low socioeconomic status on development, either with respect to household income or maternal education, at least not at nine months of age. However, although effects for household income on communication development did not reach significance, there was a trend suggesting better outcomes for infants in lower income households, which is counterintuitive. Furthermore, there were no significant interactions between household income and social environment, meaning that there was little evidence in the present study to support studies that suggest that resource dilution theory is confounded by socioeconomic status (Marjoribanks, 1997; Rodgers, 2001).

This study has some strengths and limitations that need to be considered. Its strength relates to its size and representativeness, and the breadth of information that allowed for consideration of a number of possible confounding variables. Some of the limitations have been mentioned above, but others are noteworthy. The first is that the data was crosssectional and establishing causality is therefore not possible at this stage. This also means that within the context of the present study it was only possible to examine for the effects of older siblings, though further research with follow-up data is planned. The second caveat is that all the assessments were subjective and from the mother only, and the presumption is that the assessments were unrelated to the social environmental factors under study. However, it is possible, for example, that more affluent parents set more exacting criteria for their children and thus rated them more stringently, or that parents of more than one child are 
influenced by the milestones of their older children. Although it would have been preferable to have used a measure of development such as the Bayley Scales of Infant and Toddler Development (Bayley, 2006), this was impracticable for a study of this size. However, for the most part, studies indicate that parents are able to provide accurate assessments of their child's development and behaviour (Diamond \& Squires, 1993; Glascoe \& Dworkin, 1995), and Squires et al. (1999) have found high levels of concurrence (94\%) between the parentreport ASQ and clinician assessments of developmental status. Moreover, it could be argued that the ASQ offers a validity that may sometimes be absent when the child is being assessed by a stranger, and at one point in time. A final caveat is that with a response rate of $65 \%$ there is the possibility of qualitative differences between those families who consented to take part in the GUI study and the $35 \%$ who did not respond. However, the regression models were adjusted for a range of sociodemographic and socioeconomic indicators which should help counter any biases which may exist.

\section{Conclusions and Implications}

These findings do not support the majority of research that finds positive benefits for twoparent households; similarly, the findings suggest limited effects for non-parental care. However, examination of follow-up data may elucidate these findings. The most pertinent finding was the negative effects for siblings for four of five domains of development, effects that in some instances were as strong as, if not stronger than those for physiological factors such as gestational age and birthweight. The negative effect of siblings shown in the present study supports both the confluence and resource dilution models of sibling effect, and highlights the importance of supporting parents with larger families. There was little to suggest that socioeconomic status has a negative effect on development, or that it interacts with other aspects of the infant's environment at nine months of age. However, longitudinal 
analysis would allow for a more in-depth understanding of the impact of social environment and socioeconomic status on development in early to mid-childhood.

\section{Competing interests}

None

\section{Acknowledgements}

We acknowledge the Health Research Board (Ireland) who funded the present study, and the Government of Ireland (via the Department of Children and Youth Affairs) who fund the Growing Up in Ireland study. 


\section{References}

American Academy of Pediatrics Committee on Children with Disabilities (2001).

Developmental surveillance and screening of infants and young children. Pediatrics, 108, 192-196.

Bank, L., Patterson, G. R., \& Reid, J. B. (1996). Negative sibling interaction patterns as predictors of later adjustment processes in young male adolescents. In G. H. Brody (Ed.), Sibling relationships: Their causes and consequences (pp. 197-229). Norwood, NJ: Ablex.

Bayley N. (2006). Bayley Scales of Infant and Toddler Development (3rd ed.). San Antonio (TX): Harcourt Assessment.

Belsky, J. (1979). Mother-father-infant interaction: A naturalistic observational study. Developmental Psychology, 15, 601-607.

Belsky, J. (1981). Early human experience: A family perspective. Developmental Psychology, 17, 3-23.

Belsky, J., Vandell, D. L., Burchinal, M., Clarke-Stewart, K. A., McCartney, K., Owen, M. T., \& The NICHD Early Child Care Research Network (2007). Are there long-term effects of early child care? Child Development, 78, 681-701.

Blake, J. (1981). Family size and the quality of children. Demography, 18, 421-442.

Bradley, R. H., \& Corwyn, R. F. (2002). Socioeconomic status and child development, Annual Review of Psychology, 53, 371-399.

Brauner, C. B., \& Stephens, C. B. (2006). Estimating the prevalence of early childhood serious emotional/behavioral disorders: Challenges and recommendations. Public Health Reports, 121, 303-310. 
Brettell, R., Yeh, P. S., \& Impey, L. W. M. (2008). Examination of the association between male gender and preterm delivery. European Journal of Obstetrics and Gynecology and Reproductive Biology, 141, 123-126.

Brody, G. H. (2004). Siblings' direct and indirect contributions to child development. Current Directions in Psychological Science, 13, 124-126.

Carlson, M. J., \& Corcoran, M. E. (2001). Family structure and children's behavioral and cognitive outcomes. Journal of Marriage and Family, 63, 779-792.

Cooper, J. L., Masi, R., \& Vick, J. (2009). Social-emotional development in early childhood: What every policymaker should know. National Center for Children in Poverty, Columbia University.

Diamond, K., \& Squires, J. (1993). The role of parental report in the screening and assessment of young children. Journal of Early Intervention, 17, 107-115.

Di Renzo, G. C., Rosati, A., Sarti, R. D., Cruciani, L., \& Cutuli, A. M. (2007). Does fetal sex affect pregnancy outcome? Gender Medicine, 4, 19-30.

Duncan, G. J., \& Brooks-Gunn, J. (Eds.). (1997). Consequences of growing up poor. New York: Russell Sage Foundation.

Fergusson, D., Horwood, L., \& Ridder, E. (2005). Show me the child at seven: The consequences of conduct problems in childhood for psychosocial functioning in adulthood. Journal of Child Psychology and Psychiatry, 46, 837-849.

Freijo, E. B. A., Oliva, A., Olabarrieta, F., Martín, J. L., Manzano, A., \& Richards, M. P. M. (2008). Quality of family context or sibling status? Influences on cognitive development. Early Child Development and Care, 178, 153-164.

Glascoe, F. P., \& Dworkin, P. H. (1995). The role of parents in the detection of developmental and behavioral problems. Pediatrics, 95, 829-836. 
Gray, A. (2005). The changing availability of grandparents as carers and its implications for childcare policy in the UK. Journal of Social Policy, 34, 557-577.

Hank, K., \& Buber, I. (2009). Grandparents caring for their grandchildren: Findings from the 2004 Survey of Health, Ageing, and Retirement in Europe. Journal of Family Issues, 30, 53-73.

Hetherington, E. M. (1988). Parents, children, and siblings: Six years after divorce. In R. A. Hinde \& J. Stevenson-Hinde (Eds.), Relationships within families: Mutual influences (pp. 311-331). New York: Oxford University Press.

Hofferth, S. L., \& Anderson, K. G. (2003). Are all dads equal? Biology versus marriage as a basis for paternal investment. Journal of Marriage and Family, 65, 213-232.

Jokela, M., Ferrie, J., \& Kivimaki, M. (2009). Childhood problem behaviours and death by midlife: The British National Child Development Study. Journal of the American Academy of Child and Adolescent Psychiatry, 48, 1-6.

Khong, T. Y., Adema, E. D., \& Erwich, J. J. (2003). On an anatomical basis for the increase in birth weight in second and subsequent born children. Placenta, 24, 348-353.

Koslowski, A. S. (2009). Grandparents and the care of their grandchildren. In J. Stillwell, E. Coast, \& D. Kneale (Eds.), Understanding population trends and processes: Fertility, living arrangements, care and mobility - Volume 1 (pp. 171-190). Springer Science + Business Media.

Koutra, K., Chatzi, L., Roumeliotaki, T., Vassilaki, M., Giannakopoulou, E., Batsos, C., ... Kogevinas, M. (2012). Socio-demographic determinants of infant neurodevelopment at 18 months of age: Mother-Child Cohort (Rhea Study) in Crete, Greece. Infant Behavior and Development, 35, 48-59.

Kramer, M. S. (1987). Determinants of low birth weight: Methodological assessment and meta-analysis. Bulletin of the World Health Organization, 65, 663-737. 
Kramer, M. S., Platt, R. W., Wen, S. W., Joseph, K. S., Allen, A., Abrahamowicz, M., ... Bréart, G. for the Fetal/Infant Health Study Group of the Canadian Perinatal Surveillance System (2001). A new and improved population-based Canadian reference for birth weight for gestational age. Pediatrics, 108, 1-7.

Lytton, H. (1979). Disciplinary encounters between young boys and their mothers and fathers: Is there a contingency system? Developmental Psychology, 15, 256-268.

Magnuson, K., \& Berger, L. M. (2009). Family structure states and transitions: Associations with children's well-being during middle childhood. Journal of Marriage and Family, $71,575-591$.

Marjoribanks, K. (1997). Ordinal position, family environment, and status among Australian young adults. Journal of Social Psychology, 137, 398-399.

McCormick, M. C., Litt, J. S., Smith, V. C., \& Zupancic, J. A. F. (2011). Prematurity: An overview and public health implications. Annual Review of Public Health, 32, 367379.

McLanahan, S., \& Sandefur, G. (1994). Growing up with a single parent: What hurts, what helps. Cambridge,MA: Harvard University Press.

McLoyd, V. C. (1998). Socioeconomic disadvantage and child development. American Psychologist, 53, 185-204.

Richards, M., Hardy, R., Kuh, D., \& Wadsworth, M. E. J. (2001). Birth weight and cognitive function in the British 1946 birth cohort: Longitudinal population based study. British Medical Journal, 322, 199-203.

Rodgers, J. L. (2001). What causes birth-order intelligence patterns? The admixture hypothesis revisited. American Psychologist, 56, 505-510.

Sheiner, E., Levy, A., Katz, M., Hershkovitz, R., Leron, E., \& Mazor, M. (2004). Gender does matter in perinatal medicine. Fetal Diagnosis and Therapy, 19, 366-369. 
Shonkoff, J. P., \& Phillips, D. A. (2000). From neurons to neighbourhoods: The science of early childhood development. Washington, DC: National Academy Press.

Spencer, N. (2000). Social gradients in child health: Why do they occur and what can paediatricians do about them? Ambulatory Child Health, 6, 191-202.

Squires, J., Bricker, D., \& Potter, L. (1997). Revision of a parent-completed developmental screening tool: Ages and Stages Questionnaires. Journal of Pediatric Psychology, 22, 313-328.

Squires, J., Potter, L., \& Bricker, D. (1999). The ASQ User's Guide for the Ages and Stages Questionnaire (2 ${ }^{\text {nd }}$ ed.). Baltimore: Paul H. Brookes Publishing.

Thornton, M., Williams, J., McCrory, C., Murray, A., \& Quail, A. (2013). Growing Up in Ireland National Longitudinal Study of Children: Design, instrumentation and procedures for the infant cohort at wave one (9 months), Technical Report Number 2. Dublin, Ireland: Department of Children and Youth Affairs. (accessed at http://www.growingup.ie/fileadmin/user upload/documents/Technical Reports/9 mo nth_instrumentation_report_final_18.12.13.pdf 18th February 2014)

Votruba-Drzal, E. (2003). Income changes and cognitive stimulation in young children's home learning environments. Journal of Marriage and Family, 65, 341-355.

Votruba-Drzal, E. (2006). Economic disparities in middle childhood development: Does income matter? Developmental Psychology, 42, 1154-1167.

Wilcox, M. A., Chang, A. M., \& Johnson, I. R. (1996). The effects of parity on birthweight using successive pregnancies. Acta Obstetricia et Gynecologica Scandinavica, 75, 459-463.

Wu, L. L., \& Martinson, B. C. (1993). Family structure and the risk of a premarital birth. American Sociological Review, 58, 210-232. 
Zajonc, R. B. (2001). The family dynamic of intellectual development. American Psychologist, 56, 490-496.

Zajonc, R. B., \& Markus, G. B. (1975). Birth order and intellectual development. Psychological Review, 82, 74-88. 
Table 1. Weighted frequencies and percentages for all explanatory and confounding variables included in binary logistic regressions, and crosstabulated by fails in any one domain, and fails in individual domains of the Ages and Stages Questionnaire

\begin{tabular}{|c|c|c|c|c|c|c|c|c|}
\hline & & $\mathbf{N}(\%)$ & $\begin{array}{l}\text { Any one domain } \\
\mathrm{N}(\%)\end{array}$ & $\begin{array}{l}\text { Communication } \\
\mathrm{N}(\%)\end{array}$ & $\begin{array}{l}\text { Gross motor } \\
\mathrm{N}(\%)\end{array}$ & $\begin{array}{l}\text { Fine motor } \\
\mathrm{N}(\%)\end{array}$ & $\begin{array}{l}\text { Problem-solving } \\
\mathrm{N}(\%)\end{array}$ & $\begin{array}{l}\text { Personal-social } \\
\text { N (\%) }\end{array}$ \\
\hline Partner & $\begin{array}{l}\text { Yes } \\
\text { No } \\
\end{array}$ & $\begin{array}{l}9140(85.0) \\
1607(15.0)\end{array}$ & $\begin{array}{l}652(40.6) \\
3666(40.1) \\
\end{array}$ & $\begin{array}{l}609(6.7) \\
86(5.4) \\
\end{array}$ & $\begin{array}{l}1397(15.3) \\
228(14.2) \\
\end{array}$ & $\begin{array}{l}818(9.2) \\
216(13.8) \\
\end{array}$ & $\begin{array}{l}1209(14.0) \\
237(15.5) \\
\end{array}$ & $\begin{array}{l}1601(17.7) \\
270(17.1) \\
\end{array}$ \\
\hline Siblings & \begin{tabular}{l|} 
None \\
1 \\
2 or more \\
\end{tabular} & $\begin{array}{l}4571(42.5) \\
3584(33.4) \\
2589(24.1) \\
\end{array}$ & $\begin{array}{l}1639(35.9) \\
1503(41.9) \\
1173(45.3) \\
\end{array}$ & $\begin{array}{l}285(6.3) \\
242(6.8) \\
169(6.6) \\
\end{array}$ & $\begin{array}{l}530(11.6) \\
603(16.9) \\
492(19.1) \\
\end{array}$ & $\begin{array}{l}474(10.6) \\
303(8.7) \\
258(10.3) \\
\end{array}$ & $\begin{array}{l}529(12.3) \\
479(14.1) \\
435(17.9) \\
\end{array}$ & $\begin{array}{l}571(12.7) \\
713(20.1) \\
584(22.8) \\
\end{array}$ \\
\hline Care by relative & $\begin{array}{l}\text { No } \\
\text { Yes } \\
\end{array}$ & $\begin{array}{l}8617(80.2) \\
2131(19.8) \\
\end{array}$ & $\begin{array}{l}3512(40.8) \\
807(37.9) \\
\end{array}$ & $\begin{array}{l}596(7.0) \\
99(4.7) \\
\end{array}$ & $\begin{array}{l}1337(15.6) \\
288(13.5) \\
\end{array}$ & $\begin{array}{l}837(10.0) \\
197(9.5) \\
\end{array}$ & $\begin{array}{l}1184(14.6) \\
262(12.9) \\
\end{array}$ & $\begin{array}{l}1570(18.5) \\
301(14.2) \\
\end{array}$ \\
\hline Care by non-rel & $\begin{array}{l}\text { No } \\
\text { Yes } \\
\end{array}$ & $\begin{array}{l}9274(86.3) \\
1474(13.7) \\
\end{array}$ & $\begin{array}{l}3740(40.3) \\
578(39.2) \\
\end{array}$ & $\begin{array}{l}589(6.4) \\
106(7.2) \\
\end{array}$ & $\begin{array}{l}1392(15.1) \\
233(15.9) \\
\end{array}$ & $\begin{array}{l}891(9.9) \\
143(10.0) \\
\end{array}$ & $\begin{array}{l}1251(14.3) \\
195(14.1) \\
\end{array}$ & $\begin{array}{l}1642(17.9) \\
229(15.7) \\
\end{array}$ \\
\hline Centre care & $\begin{array}{l}\text { No } \\
\text { Yes } \\
\end{array}$ & $\begin{array}{l}9569(89.0) \\
1179(11.0) \\
\end{array}$ & $\begin{array}{l}3849(40.2) \\
470(39.9) \\
\end{array}$ & $\begin{array}{l}604(6.3) \\
92(7.9) \\
\end{array}$ & $\begin{array}{l}1447(15.2) \\
178(15.1) \\
\end{array}$ & $\begin{array}{l}941(10.1) \\
93(8.2) \\
\end{array}$ & $\begin{array}{l}1318(14.6) \\
128(11.7) \\
\end{array}$ & $\begin{array}{l}1689(17.9) \\
182(15.7) \\
\end{array}$ \\
\hline Gestational age & $\begin{array}{l}25-36 \text { wks } \\
37-41 \text { wks } \\
42-46 \text { wks } \\
\end{array}$ & $\begin{array}{l}565(5.3) \\
8858(82.6) \\
1296(12.1) \\
\end{array}$ & $\begin{array}{l}341(60.4) \\
3517(39.7) \\
445(34.3) \\
\end{array}$ & $\begin{array}{l}109(19.4) \\
534(6.1) \\
52(4.0) \\
\end{array}$ & $\begin{array}{l}185(32.8) \\
1264(14.3) \\
170(13.2) \\
\end{array}$ & $\begin{array}{l}104(18.8) \\
820(9.5) \\
106(8.4) \\
\end{array}$ & $\begin{array}{l}150(27.6) \\
1166(14.0) \\
127(10.3) \\
\end{array}$ & $\begin{array}{l}163(29.3) \\
1545(17.6) \\
154(12.0) \\
\end{array}$ \\
\hline Birthweight & $\begin{array}{l}\leq 2499 \text { gms } \\
2500-3000 \text { gms } \\
3001-3500 \text { gms } \\
3501-4000 \text { gms } \\
\geq 4001 \text { gms }\end{array}$ & $\begin{array}{l}453(4.3) \\
1434(13.5) \\
3750(35.2) \\
3454(32.5) \\
1549(14.6) \\
\end{array}$ & $\begin{array}{l}268(59.2) \\
605(42.2) \\
1522(40.6) \\
1288(37.3) \\
589(38.0) \\
\end{array}$ & $\begin{array}{l}102(22.6) \\
92(6.5) \\
217(5.8) \\
199(5.8) \\
78(5.0) \\
\end{array}$ & $\begin{array}{l}138(30.5) \\
245(17.2) \\
565(15.1) \\
442(12.8) \\
221(14.3) \\
\end{array}$ & $\begin{array}{l}84(18.8) \\
165(11.9) \\
354(9.7) \\
298(8.9) \\
116(7.7) \\
\end{array}$ & $\begin{array}{l}114(26.2) \\
211(15.4) \\
496(14.1) \\
392(12.0) \\
220(15.0) \\
\end{array}$ & $\begin{array}{l}132(29.5) \\
264(18.8) \\
669(18.0) \\
544(16.0) \\
240(15.6) \\
\end{array}$ \\
\hline Gender & $\begin{array}{l}\text { Female } \\
\text { Male }\end{array}$ & $\begin{array}{l}5222(48.6) \\
5526(51.4)\end{array}$ & $\begin{array}{l}2014(38.6) \\
2305(41.7)\end{array}$ & $\begin{array}{l}267(5.1) \\
428(7.8)\end{array}$ & $\begin{array}{l}828(15.9) \\
797(14.5) \\
\end{array}$ & $\begin{array}{l}462(9.1) \\
572(10.7)\end{array}$ & $\begin{array}{l}677(13.7) \\
769(14.8) \\
\end{array}$ & $\begin{array}{l}818(15.8) \\
1053(19.4)\end{array}$ \\
\hline Mother's ethnicity & $\begin{array}{l}\text { Irish white } \\
\text { Other white } \\
\text { Black/Asian/Other }\end{array}$ & $\begin{array}{l}8947(83.5) \\
1170(10.9) \\
598(5.6) \\
\end{array}$ & $\begin{array}{l}3652(40.8) \\
423(36.2) \\
234(39.1) \\
\end{array}$ & $\begin{array}{l}560(6.3) \\
100(8.6) \\
31(5.2) \\
\end{array}$ & $\begin{array}{l}1472(16.5) \\
115(9.9) \\
34(5.7) \\
\end{array}$ & $\begin{array}{l}866(10.0) \\
102(9.0) \\
61(10.5) \\
\end{array}$ & $\begin{array}{l}1234(14.6) \\
113(10.2) \\
97(17.1) \\
\end{array}$ & $\begin{array}{l}1545(17.5) \\
190(16.5) \\
133(22.5) \\
\end{array}$ \\
\hline Mother's age group & $\begin{array}{l}16-19 \\
20-24 \\
25-29 \text { (ref) } \\
30-34 \\
35-40+ \\
\end{array}$ & $\begin{array}{l}195(1.8) \\
1115(10.4) \\
2270(21.1) \\
3779(35.2) \\
3389(31.5) \\
\end{array}$ & $\begin{array}{l}69(35.4) \\
455(40.8) \\
804(35.4) \\
1459(38.6) \\
1531(45.2) \\
\end{array}$ & $\begin{array}{l}8(4.1) \\
64(5.8) \\
129(5.7) \\
232(6.2) \\
262(7.8) \\
\end{array}$ & $\begin{array}{l}19(9.7) \\
134(12.0) \\
295(13.0) \\
561(14.9) \\
615(18.2) \\
\end{array}$ & $\begin{array}{l}32(17.3) \\
184(16.8) \\
193(8.7) \\
302(8.2) \\
323(9.9) \\
\end{array}$ & $\begin{array}{l}28(15.5) \\
163(15.1) \\
244(11.2) \\
482(13.6) \\
529(16.8) \\
\end{array}$ & $\begin{array}{l}20(10.5) \\
173(15.8) \\
361(16.0) \\
619(16.5) \\
696(20.9) \\
\end{array}$ \\
\hline Mother's education & $\begin{array}{l}\text { Higher education } \\
\text { Secondary }\end{array}$ & $\begin{array}{l}6150(57.3) \\
4586(42.7) \\
\end{array}$ & $\begin{array}{l}1916(41.8) \\
2399(39.0) \\
\end{array}$ & $\begin{array}{l}435(7.1) \\
258(5.7) \\
\end{array}$ & $\begin{array}{l}886(14.5) \\
739(16.2) \\
\end{array}$ & $\begin{array}{l}515(8.6) \\
519(11.6) \\
\end{array}$ & $\begin{array}{l}760(13.2) \\
686(15.7) \\
\end{array}$ & $\begin{array}{l}1003(16.5) \\
867(19.1) \\
\end{array}$ \\
\hline $\begin{array}{l}\text { Equivalised } \\
\text { household } \\
\text { income }\end{array}$ & $\begin{array}{l}\text { Highest (1) } \\
2 \\
3 \\
4 \\
\text { Lowest (5) } \\
\text { Missing } \\
\end{array}$ & $\begin{array}{l}1850(17.2) \\
2177(20.3) \\
1978(18.4) \\
1985(18.5) \\
1969(18.3) \\
788(7.3) \\
\end{array}$ & $\begin{array}{l}704(38.1) \\
889(40.9) \\
816(41.3) \\
794(40.0) \\
790(40.1) \\
326(41.3) \\
\end{array}$ & $\begin{array}{l}147(8.0) \\
156(7.2) \\
137(7.0) \\
104(5.2) \\
104(5.3) \\
48(6.1) \\
\end{array}$ & $\begin{array}{l}257(13.9) \\
347(16.0) \\
308(15.6) \\
291(14.7) \\
299(15.2) \\
123(15.8)\end{array}$ & $\begin{array}{l}144(8.0) \\
198(9.4) \\
183(9.5) \\
190(9.8) \\
234(12.1) \\
85(11.3) \\
\end{array}$ & $\begin{array}{l}208(12.1) \\
301(14.7) \\
270(14.3) \\
296(15.6) \\
268(14.2) \\
102(14.8)\end{array}$ & $\begin{array}{l}273(15.1) \\
357(16.6) \\
331(16.8) \\
379(19.3) \\
382(19.6) \\
150(19.5) \\
\end{array}$ \\
\hline Region & $\begin{array}{l}\text { Rural } \\
\text { Urban }\end{array}$ & $\begin{array}{l}5813(54.3) \\
4897(45.7) \\
\end{array}$ & $\begin{array}{l}1979(40.4) \\
2327(40.0) \\
\end{array}$ & $\begin{array}{l}352(6.1) \\
341(7.0) \\
\end{array}$ & $\begin{array}{l}938(16.2) \\
684(14.0) \\
\end{array}$ & $\begin{array}{l}535(9.4) \\
499(10.5) \\
\end{array}$ & $\begin{array}{l}781(14.1) \\
663(14.5) \\
\end{array}$ & $\begin{array}{l}945(16.4) \\
918(19.1) \\
\end{array}$ \\
\hline
\end{tabular}


Table 2. Results of unadjusted, sequential, and fully adjusted multivariate logistic regressions examining predictors of nine-month-old infants scoring $\geq 2$ SDs below the mean on any of the five subscales of the Ages and Stages Questionnaire

\begin{tabular}{|c|c|c|c|c|c|c|c|c|c|c|c|c|c|}
\hline & & \multicolumn{2}{|c|}{ Univariate } & \multicolumn{2}{|c|}{ 1. Social environment } & \multicolumn{2}{|c|}{ 2. Infant factors } & \multicolumn{2}{|c|}{ 3. Mother factors } & \multicolumn{2}{|c|}{$\begin{array}{l}\text { 4. Household } \\
\text { income }\end{array}$} & \multicolumn{2}{|c|}{ 5. Region } \\
\hline & & OR & $95 \% \mathrm{Cls}$ & OR & $95 \% \mathrm{Cls}$ & OR & $95 \% \mathrm{Cls}$ & OR & $95 \% \mathrm{Cls}$ & OR & $95 \% \mathrm{Cls}$ & OR & $95 \% \mathrm{Cls}$ \\
\hline & & 1.0 & & 1.0 & & 1.0 & & 1.0 & & 1.0 & & 1.0 & \\
\hline \multirow[t]{4}{*}{ Partner } & Yes & 0 & & 0 & & 0 & & 0 & & 0 & & 0 & \\
\hline & & 0.9 & & 1.0 & & 1.0 & & 1.0 & & 1.0 & & 1.0 & \\
\hline & No & 8 & $0.87,1.10$ & 5 & $0.93,1.19$ & 2 & $0.90,1.15$ & 4 & $0.90,1.19$ & 7 & $0.93,1.23$ & 6 & $0.92,1.22$ \\
\hline & & 1.0 & & 1.0 & & 1.0 & & 1.0 & & 1.0 & & 1.0 & \\
\hline \multirow[t]{4}{*}{ Siblings } & None & 0 & & 0 & & 0 & & 0 & & 0 & & 0 & \\
\hline & & 1.4 & & 1.4 & & 1.4 & & 1.3 & & 1.4 & & 1.4 & \\
\hline & 1 or more & 2 & $1.31,1.54$ & 2 & $1.31,1.54$ & 8 & $1.36,1.61$ & 9 & $1.27,1.52$ & 0 & $1.28,1.53$ & 0 & $1.27,1.53$ \\
\hline & & 1.0 & & 1.0 & & 1.0 & & 1.0 & & 1.0 & & 1.0 & \\
\hline \multirow[t]{4}{*}{ Care by relative } & No & 0 & & 0 & & 0 & & 0 & & 0 & & 0 & \\
\hline & & 0.8 & & 0.9 & & 0.9 & & 0.9 & & 0.9 & & 0.9 & \\
\hline & Yes & 8 & $0.80,0.98$ & 4 & $0.85,1.04$ & 5 & $0.85,1.05$ & 6 & $0.86,1.06$ & 4 & $0.85,1.04$ & 5 & $0.85,1.05$ \\
\hline & & 1.0 & & 1.0 & & 1.0 & & 1.0 & & 1.0 & & 1.0 & \\
\hline \multirow[t]{4}{*}{ Care by non-rel } & No & 0 & & 0 & & 0 & & 0 & & 0 & & 0 & \\
\hline & & 1.0 & & 1.0 & & 1.0 & & 1.0 & & 1.0 & & 1.0 & \\
\hline & Yes & 3 & $0.93,1.15$ & 5 & $0.94,1.17$ & 6 & $0.95,1.19$ & 5 & $0.93,1.17$ & 4 & $0.92,1.17$ & 4 & $0.93,1.17$ \\
\hline & & 1.0 & & 1.0 & & 1.0 & & 1.0 & & 1.0 & & 1.0 & \\
\hline \multirow[t]{4}{*}{ Centre care } & No & 0 & & 0 & & 0 & & 0 & & 0 & & 0 & \\
\hline & & 0.9 & & 1.0 & & 1.0 & & 1.0 & & 1.0 & & 1.0 & \\
\hline & Yes & 8 & $0.87,1.10$ & 2 & $0.90,1.15$ & 4 & $0.92,1.18$ & 2 & $0.89,1.15$ & 2 & $0.89,1.16$ & 2 & $0.89,1.16$ \\
\hline & & 2.0 & & & & 1.6 & & 1.6 & & 1.6 & & 1.6 & \\
\hline \multirow[t]{6}{*}{ Gestational age } & 25-36 wks & 3 & $1.71,2.42$ & & & 0 & $1.30,1.97$ & 3 & $1.32,2.01$ & 3 & $1.32,2.01$ & 3 & $1.32,2.01$ \\
\hline & & 1.0 & & & & 1.0 & & 1.0 & & 1.0 & & 1.0 & \\
\hline & $37-41$ wks & 0 & & & & 0 & & 0 & & 0 & & 0 & \\
\hline & & 0.7 & & & & 0.8 & & 0.8 & & 0.8 & & 0.8 & \\
\hline & $42-46$ wks & 6 & $0.67,0.86$ & & & 0 & $0.71,0.91$ & 1 & $0.71,0.92$ & 1 & $0.71,0.92$ & 1 & $0.71,0.92$ \\
\hline & & 2.0 & & & & 1.6 & & 1.6 & & 1.6 & & 1.6 & \\
\hline \multirow[t]{10}{*}{ Birthweight } & $\leq 2499 \mathrm{gms}$ & 9 & $1.71,2.57$ & & & 3 & $1.28,2.07$ & 2 & $1.27,2.06$ & 2 & $1.27,2.07$ & 2 & $1.27,2.06$ \\
\hline & & 1.0 & & & & 1.0 & & 1.0 & & 1.0 & & 1.0 & \\
\hline & $2500-3000 \mathrm{gms}$ & 5 & $0.93,1.19$ & & & 0 & $0.88,1.14$ & 1 & $0.89,1.14$ & 1 & $0.89,1.15$ & 0 & $0.88,1.14$ \\
\hline & & 1.0 & & & & 1.0 & & 1.0 & & 1.0 & & 1.0 & \\
\hline & $3001-3500 \mathrm{gms}$ & 0 & & & & 0 & & 0 & & 0 & & 0 & \\
\hline & & 0.8 & & & & 0.8 & & 0.8 & & 0.8 & & 0.8 & \\
\hline & $3501-4000 \mathrm{gms}$ & 8 & $0.80,0.97$ & & & 5 & $0.77,0.94$ & 5 & $0.77,0.94$ & 5 & $0.77,0.94$ & 5 & $0.77,0.93$ \\
\hline & & 0.8 & & & & 0.8 & & 0.8 & & 0.8 & & 0.8 & \\
\hline & $\geq 4001 \mathrm{gms}$ & 9 & $0.79,1.01$ & & & 4 & $0.75,0.96$ & 5 & $0.75,0.96$ & 5 & $0.75,0.96$ & 4 & $0.74,0.96$ \\
\hline & & 1.0 & & & & 1.0 & & 1.0 & & 1.0 & & 1.0 & \\
\hline \multirow[t]{3}{*}{ Gender } & Female & 0 & & & & 0 & & 0 & & 0 & & 0 & \\
\hline & & 1.1 & & & & 1.1 & & 1.1 & & 1.1 & & 1.1 & \\
\hline & Male & 5 & $1.07,1.24$ & & & 9 & $1.10,1.29$ & 8 & $1.09,1.27$ & 8 & $1.09,1.28$ & 8 & $1.09,1.28$ \\
\hline
\end{tabular}


Social environment and infant development 30

\begin{tabular}{|c|c|c|c|c|c|c|c|c|}
\hline & & 1.0 & 1.0 & & 1.0 & & 1.0 & \\
\hline \multirow[t]{2}{*}{ Mother's } & Irish white & 0 & 0 & & 0 & & 0 & \\
\hline & & 0.8 & 0.9 & & 0.9 & & 0.9 & \\
\hline \multirow[t]{3}{*}{ ethnicity } & Other white & $0.77,0.9$ & 5 & $0.84,1.07$ & 6 & $0.85,1.08$ & 6 & $0.85,1.08$ \\
\hline & Black/Asian/Othe & 0.9 & 0.8 & & 0.9 & & 0.9 & \\
\hline & $r$ & $0.78,1.06$ & 9 & $0.75,1.04$ & 0 & $0.76,1.06$ & 0 & $0.76,1.06$ \\
\hline & & 0.8 & 0.8 & & 0.8 & & 0.9 & \\
\hline \multirow[t]{2}{*}{ Mother's age } & $16-19$ & $0.64,1.19$ & 8 & $0.63,1.23$ & 9 & $0.64,1.25$ & 0 & $0.65,1.26$ \\
\hline & & 1.0 & 1.1 & & 1.1 & & 1.1 & \\
\hline \multirow[t]{8}{*}{ group } & $20-24$ & $0.93,1.25$ & 1 & $0.94,1.30$ & 2 & $0.95,1.32$ & 3 & $0.96,1.33$ \\
\hline & & 1.0 & 1.0 & & 1.0 & & 1.0 & \\
\hline & 25-29 (ref) & 0 & 0 & & 0 & & 0 & \\
\hline & & 1.1 & 1.1 & & 1.1 & & 1.1 & \\
\hline & $30-34$ & $1.00,1.24$ & 0 & $0.98,1.23$ & 0 & $0.98,1.23$ & 0 & $0.98,1.23$ \\
\hline & & 1.4 & 1.3 & & 1.3 & & 1.3 & \\
\hline & $35-40+$ & $1.28,1.59$ & 0 & $1.16,1.46$ & 0 & $1.15,1.46$ & 0 & $1.16,1.47$ \\
\hline & & 1.0 & 1.0 & & 1.0 & & 1.0 & \\
\hline \multirow[t]{4}{*}{ Mother's edn } & Higher education & 0 & 0 & & 0 & & 0 & \\
\hline & & 1.1 & 1.0 & & 1.0 & & 1.0 & \\
\hline & Secondary & $1.02,1.20$ & 7 & $0.98,1.18$ & 9 & $0.99,1.20$ & 9 & $0.99,1.20$ \\
\hline & & 1.0 & & & 1.0 & & 1.0 & \\
\hline \multirow[t]{2}{*}{ Equivalised } & Highest (1) & 0 & & & 0 & & 0 & \\
\hline & & 0.9 & & & 1.1 & & 1.1 & \\
\hline \multirow[t]{2}{*}{ household } & 2 & $0.79,1.10$ & & & 1 & $0.98,1.27$ & 1 & $0.98,1.27$ \\
\hline & & 1.0 & & & 1.1 & & 1.0 & \\
\hline \multirow[t]{8}{*}{ income } & 3 & $0.87,1.21$ & & & 0 & $0.96,1.26$ & 9 & $0.95,1.26$ \\
\hline & & 1.0 & & & 1.0 & & 1.0 & \\
\hline & 4 & $0.90,1.25$ & & & 1 & $0.87,1.17$ & 1 & $0.87,1.18$ \\
\hline & & 1.0 & & & 0.9 & & 0.9 & \\
\hline & Lowest (5) & $0.85,1.18$ & & & 7 & $0.83,1.14$ & 7 & $0.83,1.14$ \\
\hline & & 0.9 & & & 1.0 & & 1.0 & \\
\hline & Missing & $0.83,1.15$ & & & 4 & $0.87,1.24$ & 3 & $0.86,1.24$ \\
\hline & & 1.0 & & & & & 1.0 & \\
\hline \multirow[t]{3}{*}{ Region } & Rural & 0 & & & & & 0 & \\
\hline & & 0.9 & & & & & 1.0 & \\
\hline & Urban & $0.91,1.07$ & & & & & 3 & $0.94,1.11$ \\
\hline
\end{tabular}

Table 3. Results of fully adjusted multivariate binary logistic regressions examining predictors of nine-month-old infants scoring $\geq 2$ SDs below the mean on each of the five subscales of the Ages and Stages Questionnaire

\begin{tabular}{|c|c|c|c|c|c|c|c|c|c|c|c|}
\hline & & \multicolumn{2}{|c|}{ Communication ( $\mathrm{N}=10671)$} & \multicolumn{2}{|c|}{ Gross motor $(\mathrm{N}=10697)$} & \multicolumn{2}{|c|}{ Fine motor $(\mathrm{N}=10426)$} & \multicolumn{2}{|c|}{ Problem-solving $(\mathrm{N}=10126)$} & \multicolumn{2}{|c|}{ Personal-social $(\mathrm{N}=10612)$} \\
\hline & & OR & $95 \% \mathrm{Cls}$ & OR & $95 \%$ Cls & OR & $95 \% \mathrm{Cls}$ & OR & $95 \% \mathrm{Cls}$ & OR & $95 \%$ Cls \\
\hline Partner & Yes & 1.00 & & 1.00 & & 1.00 & & 1.00 & & 1.00 & \\
\hline & No & 1.21 & $0.91,1.62$ & 0.89 & $0.72,1.09$ & 1.12 & $0.90,1.39$ & 1.07 & $0.88,1.30$ & 0.94 & $0.78,1.13$ \\
\hline Siblings & None & 1.00 & $116 \quad 171$ & 1.00 & 140185 & 1.00 & 084117 & 1.00 & $108 \quad 145$ & 1.00 & 151196 \\
\hline
\end{tabular}


Social environment and infant development 31

\begin{tabular}{|c|c|c|c|c|c|c|c|c|c|c|c|}
\hline & 2 or more & 1.37 & $1.08,1.73$ & 1.76 & $1.50,2.08$ & 1.01 & $0.83,1.23$ & 1.54 & $1.30,1.82$ & 1.79 & $1.54,2.09$ \\
\hline \multirow[t]{2}{*}{ Care by relative } & No & 1.00 & & 1.00 & & 1.00 & & 1.00 & & 1.00 & \\
\hline & Yes & 0.70 & $0.55,0.87$ & 0.88 & $0.76,1.03$ & 0.90 & $0.75,1.07$ & 0.98 & $0.84,1.14$ & 0.84 & $0.73,0.97$ \\
\hline \multirow[t]{2}{*}{ Care by non-rel } & No & 1.00 & & 1.00 & & 1.00 & & 1.00 & & 1.00 & \\
\hline & Yes & 1.09 & $0.87,1.36$ & 1.12 & $0.95,1.31$ & 1.16 & $0.95,1.40$ & 1.12 & $0.95,1.32$ & 0.97 & $0.83,1.13$ \\
\hline \multirow[t]{2}{*}{ Centre care } & No & 1.00 & & 1.00 & & 1.00 & & 1.00 & & 1.00 & \\
\hline & Yes & 1.17 & $0.92,1.49$ & 1.05 & $0.88,1.26$ & 0.93 & $0.74,1.17$ & 0.90 & $0.74,1.10$ & 1.03 & $0.87,1.23$ \\
\hline \multirow[t]{3}{*}{ Gestational age } & $25-36$ wks & 1.71 & $1.23,2.38$ & 2.06 & $1.60,2.65$ & 1.86 & $1.40,2.49$ & 1.77 & $1.37,2.30$ & 1.49 & $1.17,1.92$ \\
\hline & $37-41$ wks & 1.00 & & 1.00 & & 1.00 & & 1.00 & & 1.00 & \\
\hline & $42-46$ wks & 0.75 & $0.56,1.00$ & 0.95 & $0.79,1.15$ & 0.90 & $0.72,1.13$ & 0.80 & $0.65,0.97$ & 0.71 & $0.59,0.85$ \\
\hline \multirow[t]{5}{*}{ Birthweight } & $\leq 2499 \mathrm{gms}$ & 2.89 & $2.02,4.14$ & 1.72 & $1.28,2.31$ & 1.34 & $0.96,1.88$ & 1.53 & $1.13,2.06$ & 1.46 & $1.10,1.94$ \\
\hline & $2500-3000 \mathrm{gms}$ & 1.07 & $0.82,1.38$ & 1.18 & $0.99,1.41$ & 0.99 & $0.80,1.22$ & 1.01 & $0.84,1.22$ & 1.00 & $0.85,1.18$ \\
\hline & $3001-3500 \mathrm{gms}$ & 1.00 & & 1.00 & & 1.00 & & 1.00 & & 1.00 & \\
\hline & $3501-4000 \mathrm{gms}$ & 0.93 & $0.77,1.13$ & 0.85 & $0.74,0.97$ & 0.90 & $0.76,1.06$ & 0.85 & $0.73,0.98$ & 0.87 & $0.77,0.99$ \\
\hline & $\geq 4001 \mathrm{gms}$ & 0.76 & $0.58,0.99$ & 0.94 & $0.79,1.12$ & 0.81 & $0.65,1.02$ & 0.99 & $0.83,1.19$ & 0.81 & $0.68,0.95$ \\
\hline \multirow[t]{2}{*}{ Gender } & Female & 1.00 & & 1.00 & & 1.00 & & 1.00 & & 1.00 & \\
\hline & Male & 1.56 & $1.33,1.83$ & 0.91 & $0.82,1.02$ & 1.23 & $1.08,1.41$ & 1.17 & $1.04,1.32$ & 1.32 & $1.19,1.46$ \\
\hline Mother's & Irish white & 1.00 & & 1.00 & & 1.00 & & 1.00 & & 1.00 & \\
\hline \multirow[t]{2}{*}{ ethnicity } & Other white & 1.58 & $1.27,1.97$ & 0.64 & $0.53,0.78$ & 0.95 & $0.77,1.17$ & 0.77 & $0.64,0.94$ & 1.09 & $0.93,1.27$ \\
\hline & Black/Asian/Other & 0.78 & $0.54,1.12$ & 0.26 & $0.18,0.37$ & 0.93 & $0.71,1.23$ & 1.06 & $0.84,1.33$ & 1.21 & $0.99,1.47$ \\
\hline \multirow{5}{*}{$\begin{array}{l}\text { Mother's age } \\
\text { group }\end{array}$} & $16-19$ & 0.83 & $0.38,1.80$ & 0.71 & $0.41,1.23$ & 1.74 & $1.12,2.69$ & 1.36 & $0.86,2.13$ & 0.67 & $0.40,1.11$ \\
\hline & $20-24$ & 1.06 & $0.75,1.50$ & 0.99 & $0.78,1.27$ & 1.52 & $1.19,1.94$ & 1.30 & $1.03,1.64$ & 0.97 & $0.78,1.20$ \\
\hline & $25-29$ (ref) & 1.00 & & 1.00 & & 1.00 & & 1.00 & & 1.00 & \\
\hline & $30-34$ & 1.02 & $0.81,1.29$ & 1.13 & $0.96,1.33$ & 0.93 & $0.77,1.14$ & 1.15 & $0.97,1.36$ & 1.00 & $0.86,1.16$ \\
\hline & $35-40+$ & 1.22 & $0.96,1.55$ & 1.22 & $1.03,1.45$ & 1.12 & $0.91,1.37$ & 1.32 & $1.11,1.58$ & 1.17 & $1.00,1.36$ \\
\hline \multirow[t]{2}{*}{ Mother's edn } & Higher education & 1.00 & & 1.00 & & 1.00 & & 1.00 & & 1.00 & \\
\hline & Secondary & 0.85 & $0.70,1.04$ & 1.11 & $0.98,1.27$ & 1.21 & $1.03,1.41$ & 1.12 & $0.97,1.28$ & 1.06 & $0.94,1.20$ \\
\hline \multirow{6}{*}{$\begin{array}{l}\text { Equivalised } \\
\text { household } \\
\text { income }\end{array}$} & Highest (1) & 1.00 & & 1.00 & & 1.00 & & 1.00 & & 1.00 & \\
\hline & 2 & 0.89 & $0.69,1.14$ & 1.20 & $1.00,1.44$ & 1.14 & $0.91,1.44$ & 1.18 & $0.97,1.43$ & 1.15 & $0.96,1.37$ \\
\hline & 3 & 0.94 & $0.72,1.22$ & 1.09 & $0.90,1.33$ & 1.10 & $0.86,1.41$ & 1.11 & $0.90,1.36$ & 1.06 & $0.88,1.28$ \\
\hline & 4 & 0.67 & $0.50,0.90$ & 1.00 & $0.81,1.23$ & 1.09 & $0.84,1.40$ & 1.14 & $0.92,1.42$ & 1.22 & $1.00,1.48$ \\
\hline & Lowest (5) & 0.60 & $0.44,0.82$ & 1.04 & $0.84,1.31$ & 1.07 & $0.82,1.40$ & 0.98 & $0.78,1.24$ & 1.18 & $0.96,1.45$ \\
\hline & Missing & 0.72 & $0.50,1.04$ & 1.13 & $0.88,1.46$ & 1.05 & $0.77,1.43$ & 1.13 & $0.86,1.48$ & 1.21 & $0.95,1.53$ \\
\hline \multirow[t]{2}{*}{ Region } & Rural & 1.00 & & 1.00 & & 1.00 & & 1.00 & & 1.00 & \\
\hline & Urban & 1.13 & $0.96,1.33$ & 0.92 & $0.82,1.03$ & 1.11 & $0.97,1.27$ & 1.00 & $0.89,1.13$ & 1.18 & $1.06,1.31$ \\
\hline
\end{tabular}

